\title{
IN VITRO TRANSFER OF L-ALANINE, L-HISTIDINE AND CARNOSINE ACROSS THE RUMEN EPITHELIUM OF SHEEP
}

\author{
S. FAIX ${ }^{1}$, Z. FAIXOVÁ2 \\ ${ }^{1}$ Institute of Animal Physiology, Slovak Academy of Sciences, Košice, ${ }^{2}$ Department of Pathological Physiology, \\ University of Veterinary Medicine, Košice, Slovak Republic
}

Received March 26, 2001

Accepted August 28, 2001

\begin{abstract}
Faix S̆., Z. Faixová: In vitro Transfer of L-alanine, L-histidine and Carnosine across the Rumen Epithelium of Sheep. Acta Vet. Brno 2001, 70: 243-246.

The objectives of this experiment were to study the transfer of free amino acids (alanine, histidine) and dipeptide (carnosine) of different concentrations from the mucosal to the serosal side of the rumen epithelium after 60 min of incubation in vitro. Experiments were carried out on the rumen epithelium taken from twenty four young sheep. The transfer of alanine and carnosine was not significantly different between concentrations of 0.5 and $1 \mathrm{mmol} .1^{-1}$. Only the transfer of histidine increased in both cases from $0.036 \pm 0.007$ to $0.074 \pm 0.002 \mathrm{mmol}^{-1} \mathrm{l}^{-1}$. The transfer of histidine rose with increasing concentration from $1 \mathrm{mmol}^{-1}$ to 5 or $10 \mathrm{mmol}^{-1}$ (from $0.074 \pm$

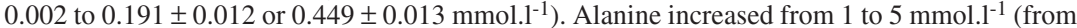
$0.037 \pm 0.005$ to $0.163 \pm 0.007$ ) but the $10 \mathrm{mmol}^{-1} \mathrm{l}^{-1}$ concentration did not affect transfer of alanine $\left(0.184 \pm 0.054 \mathrm{mmol} . \mathrm{l}^{-1}\right)$. The opposite result was found in carnosine. The $5 \mathrm{mmol} . \mathrm{l}^{-1}$ concentration did not affect the transfer of carnosine compared with $1 \mathrm{mmol}^{-1} \mathrm{l}^{-1}(0.048 \pm 0.004$ v.s. $0.036 \pm 0.005 \mathrm{mmol}^{-1} \mathrm{l}^{-1}$ ) but the transfer of carnosine was six times higher in the $10 \mathrm{mmol} . \mathrm{l}^{-1}$ versus $5 \mathrm{mmol} . \mathrm{l}^{-1}\left(0.273 \pm 0.055\right.$ v.s. $\left.0.048 \pm 0.004 \mathrm{mmol}^{-1} \mathrm{l}^{-1}\right)$. The results of this study indicate that amino acids can transfer more easily through the rumen wall in lower initial concentrations than the dipeptide carnosine can.

Sheep, amino acids, dipeptide, rumen epithelium
\end{abstract}

The rumen epithelium has the ability to absorb, metabolise, and excrete protein and nonprotein nitrogen substances (Várady 1985). The main part of the dietary protein is degraded by rumen microorganisms to amino acids and peptides. The amino acids are incorporated into microbial protein or degraded into $\alpha$-keto acids and ammonia or passed from the rumen to next parts of the digestive tract or absorbed directly across the rumen wall into the blood. The amount of amino acids absorbed across rumen wall represents about $10 \%$ of the total nitrogen which is absorbed into the blood from the rumen (Hoover and Miller 1991). The transfer of amino acids across the rumen epithelium depends on the concentration of $\alpha$-amino nitrogen in the rumen (Leng et al. 1978), the $\mathrm{pH}$ of the rumen contents (Leibholz 1971), the morphological parts of the rumen wall (Faix ová and Várady 1997), and the interaction between amino acids (Fai x ová and Várady 1994).

Our previous results showed that the absorption of free amino acids across the rumen epithelium is more effective at lower concentrations of amino acids on the mucosal side of the rumen epithelium (Feješ et al. 1991; Faix ová and Várady 1994). The concentration of peptides in the rumen depends on the degradation rate of dietary and microbial protein (Chen and Russell 1991) and on the quality of dietary protein and the frequency of feeding (Williams and Cockburn 1991). Our goal was to compare the transfer of free amino acids and dipeptide across the rumen epithelium at different concentrations on the mucosal side of the rumen epithelium in sheep.

Address for correspondence:

MVDr. Zita Faixová

MVDr. Zita Faixová
University of Veterinary Medicine
Komenského 73

04181 Košice, Slovak Republic
Phone: +421 556325841

E-mail: zita faixova@vim

http://www.vfu.cz/acta-vet/actavet.htm 


\section{Materials and Methods}

The experiment was carried out on 24 young ewes (Ovis aries) weighing between 30 and $35 \mathrm{~kg}$. The animals were housed individually, fed twice daily, and had free access to water. The total daily ration of each sheep consisted of $400 \mathrm{~g}$ of mixed diet (containing $12 \%$ beetroot molasses, $12 \%$ oats, $48 \%$ wheat and rye bran, $12 \%$ meal and $2 \%$ mineral supplement) and $1000 \mathrm{~g}$ of hay providing $1177.6 \mathrm{~g}$ of dry matter, $23.22 \mathrm{~g}$ of nitrogen and $6.48 \mathrm{MJ}$ of net energy of lactation. Throughout the experiment, the animals were maintained according to the principles governing the care of laboratory animals.

The sheep were killed by an overdose of pentobarbitalum natricum (Pentobarbital, Spofa). The abdominal cavity was opened and the rumen was removed. The digesta were removed by rinsing with tap water and with cold saline. Three samples of the rumen wall measuring $6 \mathrm{~cm} \times 6 \mathrm{~cm}$ approximately were collected from the dorsal sack of the rumen. The tissue was then placed in an oxygenated Tyrode solution, $\mathrm{pH}$ 7.4. The solution was oxygenated 1 hour before use. The epithelium of the rumen was stripped from the underlying muscle layer and fixed in the top of a polyethylene tube with an inner diameter of $45 \mathrm{~mm}$. The mucosal side of the epithelium faced the inside of the tube. The tubes were filled with $50 \mathrm{ml}$ of Tyrode solution containing $0.5,1,5,10 \mathrm{mmol} . \mathrm{l}^{-1}$ concentrations of alanine, histidine and carnosine, respectively, with the $\mathrm{pH}$ adjusted to 6.9. They were placed in glass vessels containing 150 $\mathrm{ml}$ of Tyrode solution with the $\mathrm{pH}$ adjusted to 7.4. The solutions in both chambers were mixed by an electric blender. The glass vessels were placed in a waterbath at $39{ }^{\circ} \mathrm{C}$.

The time that elapsed from removal of the rumen from the sheep to the beginning of the incubation was 10 min approximately. Concentrations of alanine, histidine and carnosine were measured after 60 min of incubation by the chromatographic methods on an Automatic amino acid analyser (AAT 339, Microtechna, Praha).

The results of the analysis are given as the mean \pm SEM. The statistical significance of the differences in values were determined by ANOVA.

\section{Results}

Table 1 shows the concentrations of alanine, histidine and carnosine on the serosal side of the rumen epithelium. The concentration of carnosine was lower compared with alanine for 0.5 mmol. $\mathrm{l}^{-1}(P<0.05)$ and $5 \mathrm{mmol}^{-1} \mathrm{l}^{-1}(P<0.001)$ concentrations, with no significant differences for $1 \mathrm{mmol.} \mathrm{l}^{-1}$ and $10 \mathrm{mmol.1} \mathrm{l}^{-1}$ concentrations.

Table 1

Concentration of L-alanine, L-histidine, and carnosine on the serosal side of the rumen epithelium in sheep after 60 minutes incubation in vitro

\begin{tabular}{|c|c|c|c|}
\hline \multirow{3}{*}{$\begin{array}{c}\text { Mucosal side of rumen } \\
\text { epithelium }\end{array}$} & \multicolumn{3}{|c|}{ Serosal side of rumen epithelium } \\
\hline & Alanine & Histidine & Carnosine \\
\hline & mmol.1-1 & mmol.1 $1^{-1}$ & mmol.1-1 \\
\hline $0.5 \mathrm{mmol}^{-1} \mathrm{1}^{-1}$ & $0.048 \pm 0.006^{\mathrm{a}}$ & $0.036 \pm 0.007$ & $0.021 \pm 0.004^{\mathrm{a}}$ \\
\hline $1 \mathrm{mmol}^{-1} \mathrm{1}^{-1}$ & $0.037 \pm 0.005^{\mathrm{a}}$ & $0.074 \pm 0.002^{\mathrm{ab}}$ & $0.036 \pm 0.005^{\mathrm{b}}$ \\
\hline $5 \mathrm{mmol}^{-1} \mathrm{l}^{-1}$ & $0.163 \pm 0.007^{\mathrm{a}}$ & $0.191 \pm 0.012^{b}$ & $0.048 \pm 0.004^{\mathrm{ab}}$ \\
\hline
\end{tabular}

Values are means $\pm S E M, n=6$. Significant differences $(\mathrm{P}<0.01)$ within a row are indicated by using the same superscript letters.

Lower concentrations of carnosine compared with histidine were measured for 1 mmol. $\mathrm{l}^{-1}(P<0.001), 5 \mathrm{mmol} . \mathrm{l}^{-1}(P<0.001)$ and $10 \mathrm{mmol}^{-1} \mathrm{l}^{-1}(P<0.05)$, with no significant differences for $0.5 \mathrm{mmol}^{-1}$ concentrations. The significant differences between free amino acids were determined for $1 \mathrm{mmol}^{-1}(P<0.001)$ and $10 \mathrm{mmol}^{-1} \mathrm{l}^{-1}$ $(P<0.01)$ concentrations only.

The transfer of alanine and carnosine was not different between $0.5 \mathrm{mmol} . \mathrm{l}^{-1}$ and 1 mmol. $1^{-1}$ concentration. Only the transfer of histidine increased twofold. The transfer of histidine rose with increasing concentration from $1 \mathrm{mmol}^{-1}$ to 5 or $10 \mathrm{mmol}^{-1}$. The alanine increased from $1 \mathrm{mmol} . \mathrm{l}^{-1}$ to $5 \mathrm{mmol} . \mathrm{l}^{-1}$ but $10 \mathrm{mmol}^{-1}$ concentration did not affect the transfer of alanine. The opposite result was recorded for carnosine. $5 \mathrm{mmol} . \mathrm{l}^{-1}$ concentration 
did not affect the transfer of carnosine compared with 1 mmol. $\mathrm{l}^{-1}$ but the transfer of carnosine was six times higher in 10 mmol. $\mathrm{l}^{-1}$ compared with 5 mmol. $\mathrm{l}^{-1}$.

\section{Discussion}

The transfer analysis of alanine, histidine and carnosine used in this experiment clearly shows the difference between the concentrations of free amino acids and dipeptide. The peptide transport mechanisms have been identified in the liver (Lo mbardo et al. 1988; Fei et al. 1994), kidney and brain (Fei et al. 1994). The stomach tissue was identified as a major site of peptide uptake in ruminants, when ruminal and omasal epithelial tissues were used (Webb et al. 1993). Measurements of net flux of peptide amino acids in the portal and the mesenteric vein of ruminants (Webb et al. 1992; Seal and Parker 1996) showed that the nonmesenteric drainage releases large amounts of peptides to the liver. Peptide absorption from the stomach was postulated to explain this phenomenon. However, in another study (B ackwell et al. 1997), no significant release of peptide amino acids was observed in the mesenteric vein or in the portal vein. Thwaites et al. (1993) showed the presence of the proton-coupled peptide transporter in the epithelial tissues on both the apical and basolateral membranes in the gut. Matthews and Webb (1995) demonstrated the ability of ruminal and omasal epithelial tissue to absorb Met and Met-Gly by a non-mediated process, which depends on the relative concentration in the forestomach content. Leib holz (1971) showed that the transfer of histidine across the isolated rumen epithelium was reduced in the presence of other amino acids at equimolar concentrations (arginine 50\%, lysine 30\%, leucine 10\%). Our previous results (Faix ová and Várady 1994) indicated the interactions between neutral and basic amino acids during the transport across the rumen epithelium in the mucosal-serosal direction. It assumes the presence of an amino acid transport system in the rumen epithelium at least for some amino acids. Rémond et al. (2000) show that after intraruminal injections of solutions containing increasing amounts of free amino acids and carnosine, free amino acids uptake decreased and net carnosine release increased linearly. According to Matthews and Payne (1975) the transport of peptides occurs by transport systems different from the transporters of free amino acids. The dipeptide transport across the rumen epithelium has been described, but its exact mechanism remains to be clarified. We suggest that the transfer of dipeptide is affected by peptide hydrolysis with the subsequent transport of free amino acids.

In conclusion, the results of this experiment show that concentration of amino acids on the mucosal side of rumen epithelium is very important factor for transfer across the rumen epithelium. Further investigations are required to determine the capacity of the rumen wall to absorb amino acids.

\section{Transfer L-alanínu, L-histidínu a karnozínu cez bachorový epitel in vitro}

Cielom tohto experimentu bolo sledovat transfer rôznych koncentrácií volných aminokyselín (alanín, histidín) a dipeptidu (karnozín) z mukóznej na seróznu stranu epitelu bachora po 60 minútovej inkubácii in vitro. Pokusy boli robené na epiteli bachora z dvadsiatich štyroch oviec. Transfer alanínu a karnozínu nebol signifikantne rozdielny medzi 0,5 and 1 mmol. $1^{-1}$ koncentráciami. Iba transfer histidínu sa dvojnásobne zvýšil z $0.036 \pm 0.007$ na $0.074 \pm 0.002 \mathrm{mmol}^{-\mathrm{l}^{-1}}$. Transfer histidínu stúpal so zvyšujúcou sa koncentráciou z $1 \mathrm{mmol}^{-1}$, na 5 alebo $10 \mathrm{mmol}^{-1}$ ( z $0.074 \pm 0.002$, na $0.191 \pm 0.012$ alebo $\left.0.449 \pm 0.013 \mathrm{mmol} . \mathrm{l}^{-1}\right)$. Alanín sa zvýšil z 1 na $5 \mathrm{mmol}^{-1} \mathrm{l}^{-1}$ ( $0.037 \pm 0.005$ na 0.163 $\pm 0.007)$, ale $10 \mathrm{mmol}^{-1} \mathrm{l}^{-1}$ koncentrácia neovplyvnila transfer alanínu $(0.184 \pm 0.054$ mmol. $\left.\mathrm{l}^{-1}\right)$. Opačný výsledok bol nameraný u karnozínu. Koncentrácia $5 \mathrm{mmol} . \mathrm{l}^{-1}$ neovplyvnila transfer karnozínu oproti $1 \mathrm{mmol}^{-1} \mathrm{l}^{-1}(0.048 \pm 0.004$ v.s. $0.036 \pm 0.005$ 


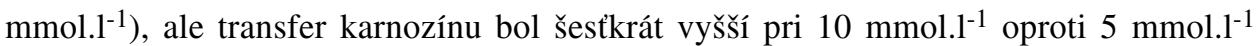
$\left(0.273 \pm 0.055\right.$ v.s. $\left.0.048 \pm 0.004 \mathrm{mmol}^{-1} \mathrm{l}^{-1}\right)$. Tieto výsledky ukazujú, že nižšia iniciálna koncentrácia alanínu, histidínu a karnozínu na mukóznej strane epitelu bachora je dôležitejším faktorom pre transfer volných aminokyselín než pre dipeptidy.

\section{Acknowledgements}

This study was supported by grant no. 1/5146/98 and no. 2/7028/20 from the Grant Agency for Science,VEGA, Slovak Republic.

\section{References}

BACKWELL, F. R. C., HIPOLITO-REIS, M., WILSON, D., BRUCE, L. A., BUCHAN, V., MacRAE, J. C. 1997: Quantification of circulating peptides and assessment of peptide uptake across the gastrointestinal tract of sheep. J. Anim. Sci. 75: $3315-3322$

CHEN, G., RUSSELL, J. B. 1991: Effect of monensin and a protonophore on protein degradation, peptide accumulation and deamination by mixed ruminal microorganisms in vitro. J. Anim. Sci. 69: 2196-2201

FAIXOVÁ, Z., VÁRADY, J. 1994: Amino acid transfer through the rumen epithelium in sheep: leucine and lysine interactions. Vet. Med.- Czech 39: 255-262

FAIXOVÁ, Z., VÁRADY, J. 1997: Amino acid uptake by the sheep rumen epithelium. Vet. Med. - Czech 42: 61-65 Fei, Y.-J., Kanai, Y., Nussberger, S., Ganapathy, V., Liebach, F. H., Romero, M. F., Singh, S. K., Boron, W. F., Hediger, M. A. 1994: Expression cloning of a mammalian proton-coupled oligopeptide transporter. Nature (Lond.) 368: 563-566

FEJEŠ, J., FAIXOVÁ, Z., VÁRADY, J., CIBULA, M. 1991: Transfer of amino acids through mucous rumen membrane of sheep in vitro. Vet. Med. (Praha) 36: 551-559

HOOVER, W. H., MILLER, T. K. 1991: Rumen digestive physiology and microbial ecology. Vet. Clin. N. Amer.Food Anim. Pr. 7: 311-325

LEIBHOLZ, J. 1971: The absorption of amino acids from the rumen of sheep. II. The transfer of histidine, glycine and ammonia across the rumen epithelium in vitro. Austr. J. Agric. Res. 22: 647-653

LENG, L., TOMÁŚ, J., BAJO, M., VÁRADY, J., SZÁNYIOVÁ, M. 1978: Resorpcia aminokyselín z perfundovaného bachora oviec. Vet. Med. (Praha) 23: 337-345

LOMBARDO, Y. B., MORSE, E. L., ADIBI, S. A. 1988: Specificity and mechanism of influence of amino acid residues on hepatic clearance of oligopeptides. J. Biol. Chem. 263: 12920-12926

MATTHEWS, D. M., PAYNE, J. W. 1975: Peptide transport in protein nutrition, North-Holland, Amsterdam, $503 \mathrm{p}$.

MATTHEWS, J. C., WEBB, K. E. JR. 1995: Absorption of L-carnosine, L-methionine, and L-methionylglycine by isolated sheep ruminal and omasal epithelial tissue. J. Anim. Sci. 73: $3464-3475$

RÉMOND, D., BERNARD, L., PONCET, C. 2000: Amino acid flux in ruminal and gastric veins of sheep: Effects of ruminal and omasal injections of free amino acids and carnosine. J. Anim. Sci. 78: 158-166

SEAL, C. J., PARKER, D. S. 1996: Effect of intraruminal propionic acid infusion on metabolism of mesentericand portal-drained viscera in growing steers fed a forage diet: II. Ammonia, urea, amino acids, and peptides. J. Anim. Sci. 74: 245-256

THWAITES, D. T ., BROWN, C. D. A., HIRST, B. H., SIMMONS, N. L. 1993: Transepithelial glycylsarcosine transport in intestinal CacO-2 cells mediated by expression of $\mathrm{H}(+)$-coupled carriers at both apical and basal membranes. J. Biol. Chem. 268: 7640-7642

VÁRADY, J. 1985: Exchange processes of nitrogenous compounds between the blood and the digestive tract in ruminants. Agricultural Science, 1/85: pp 140-141.

WEBB, K. E., DIRIENZO, D. B., MATTHEWS, J. C. 1993: Recent developments in gastrointestinal absorption and tissue utilization of peptides: A review. J.Dairy Sci. 76: 351-361

WEBB, K. E., JR., MATTHEWS, J. C., DIRIENZO, D. B. 1992: Peptide absorption: A review of current concepts and future perspectives. J. Anim. Sci. 70: 3248-3257

WILLIAMS, A. P., COCKBURN, J. E. 1991: Effect of slowly and rapidly degraded protein sources on the concentrations of amino acids and peptides in the rumen of steers. J. Sci. Food Agric. 56: 303-314 